plan with vertical stiffenings, and the structure is believed to be the only one of the kind in the United States, although the principle is used very extensively in modified forms on the German, Russian, and Italian railways.

\title{
TESTING STEAM-BOILERS.
}

BY S. W. RoBinson,

Assistant Professor of Mining Engineering and Geodesy, University of Michigan.

IT is generally believed that steam-boilers become weakened, for resistance to internal pressure, after continued use, from various known and unknown causes; so that the engineer cannot judge of the pressure to which his boiler can be worked with safety. But this he may determine by a very simple process, and means which are always at his command. It is as follows:-Let the boiler be filled entirely full of cold water, even to the throttle and safetyvalves, and all closed tight to prevent any escape. Now, by lighting a fire under the boiler, the water will be gradually expanded, and produce a pressure sufficient even to rupture the iron before the temperature of the water arrives at the boiling point. While the pressure is increasing, let the steam-gauge or pressure indicator be watched; and when the test pressure, which may be twice or more times as great as the working pressure, is reached, a portion of the water may be allowed to escape and the pressure reduced. The pressure results from the fact that water is expanded more by heat than iron. The process above given is attended with as much safety as the use of the hydrostatic press, unless the water be heated above $212^{\circ}$, which would not be required unless the boiler leaks. Below this temperature no disastrous consequences would follow, even if the boiler should be torn asunder, inasmuch as explosions result from the sudden expansion of gases or vapors.

Ann Arbor, Michigan, December 9th, 1867.

The Wilmington and Reading Railroad, which is to be built during the present year, starts from Wilmington and runs over the high grounds on the west side of the Brandywine, entering the valley of that stream ten miles from Wilmington, at Twaddle's Ford, and follows the west branch of the Brandy wine through Coatesville, and crossing over the East Brandywine near Isabella Furnace, thence by Springfield and Jones's Mines down the valley of Hay Creek to the Philadelphia and Reading Railroad, at Birdsboro'. The length of the road will be fifty-five miles, and estimated cost $\$ 1,664,000$. 